\title{
Tahap-tahap Menyelesaikan Masalah Geometri melalui Interaksi Berpikir pada Aktivitas Kognitif Siswa SMP
}

\author{
Syarifudin $^{1, *}$, Ummu Fikriyah $^{2}$ \\ ${ }^{1}$ STKIP Taman Siswa Bima \\ ${ }^{2}$ SMPN 4 Nguling \\ *syarifudinsyarif745@gmail.com
}

\begin{abstract}
Abstrak: Perubahan pengetahuan siswa sebagai hasil pengalaman belajar merupakan hal utaman yang diharapkan dalam proses pembelajaran. Perubahan pengetahuan itu salah satunya melalui kegiatan interaksi berpikir. Tujuan dalam penelitian ini untuk mendeskripsikan tahap-tahap aktivitas kognitif siswa melalui kegiatan interakasi berpikir dalam memecahkan masalah geometri. Penelitian ini dilaksanakan pada 5 orang siswa SMP yang berkemampuan tinggi dan sedang. Hasil penelitian menunjukkan bahwa kegiatan kelima siswa dalam mendiskusikan permasalahan yang diawali dari siswa yang berkemampuan tinggi memberikan penjelasan tentang cara menjawab soal yang diberikan. Siswa yang lainnya mendengarkan dan kadang-kadang merespon dari penjelasan yang disampaikan oleh siswa yang berkemampuan tinggi tersebut. Kegiatan selanjutnya adalah mereka bersama-sama mendiskusikan dan saling membantu untuk mencari solusi dari permasalah yang diberikan dengan menyampaikan pertanyaan atau penjelasan antara satu siswa dengan siswa yang lainnya. Kegitan ini terus dilakukan sampai menemukan satu solusi yang tepat untuk diputuskan bersama-sama lalu ditulis dalam lembar jawaban masing-masing. Setelah mereka menulis jawaban masing-masing, ternyata bentuk jawaban yang dituliskan berbeda-beda dan ada juga yang masih melihat jawaban dari temannya.
\end{abstract}

Kata Kunci: Aktivitas Kognitif, Interkasi Berpikir, Masalah Geometri

\section{Pendahuluan}

Pendidikan Perubahan pengetahuan matematika siswa sebagai hasil pengalaman belajar merupakan target utama dalam pelaksanaan pembelajaran matematika. Perubahan pengetahuan siswa ini harus dibantu melalui kegiatan interaksi baik dengan dirinya, siswa lain, guru, maupun dengan lingkungannya. Anderson \& Krathwohl, (2010) mengungkapkan bahwa siswa harus mengkontruksi pengetahuan dari lingkungan, berinteraksi dengan pengalaman dan objek yang dihadapi, dan mengadakan abstraksi, baik secara sederhana maupun reflektif. Lebih lanjut Strom, dkk., (2001) bahwa belajar matematika adalah suatu proses aktif, dimana setiap siswa membangun pengetahuan matematikanya sendiri dari pengalaman dan pengetahuan sebelumnya. Melakukan kegiatan interaksi dalam mengkonstruksi pengetahuan merupakan salah satu cara yang harus dilakukan oleh siswa. Berinteraksi membutuhkan keterlibatan orang lain atau lingkungan agar mendapatkan hasil yang maksimal. Johnson, dkk., (2014) menyarankan keterlibatan anggota kelompok dalam kegiatan diskusi dapat memberikan kontribusi yang maksimal bagi setiap anggota kelompok sehingga mempermudah mencapai tujuan yang diharapkan bersama.

Keterlibatan siswa secara aktif dalam kegiatan diskusi kelompok merupakan cara yang dapat membantu siswa untuk mengkonstruksi pengetahuannya sendiri. Untuk mendukung hal tersebut, guru harus memberikan kesempatan seluas-luasnya kepada siswanya dalam kegiatan diskusinya. Hal ini sejalan dengan yang disaran oleh Stockero \& Van Zoest, (2013) dan Santagata, dkk., (2007). Stockero \& Van Zoest, (2013) menyarankan kepada guru agar bersabar tidak memberitahu terlebih dahulu ketika ada masalah yang dihadapai siswa dalam pelaksanaan pembelajaran dan diharapkan diberikan kesempatan kepada siswa memperbaiki dan mencari solusinya terlebih dahulu. Santagata, dkk (2007) menyarankan agar memberikan kesempatan kepada siswa dalam menyelesaikan masalah matematika sampai mereka mendapatkan kesulitan dan perlu dibantu oleh guru. 
Kehadiran guru memang perlu, namun memerlukan caranya dan waktu yang tepat. Pelaksanaan pembelajaran dengan diskusi berkelompok dapat mengurangi keikutsertaan guru pada saat proses pembelajaran. Hal ini sejalan dengan pendapatnya Kidron, dkk., (2008) bahwa pembelajaran matematika yang signifikan tidak dapat dicapai apabila pekerjaan siswa terlalu banyak bergantung pada guru. Oleh karena itu, guru harus paham dan tahu hubungan interaksi antara siswa yang satu dengan yang lainnya dalam diskusi kelompoknya.

Kegaitan diskusi kelompok yang melibatkan multiinteraksi merupakan hal yang sangat diperlukan dalam proses pembelajaran. Bishop (2012) mengkaji kegiatan interaksi siswa dalam kelompok untuk memposisikan diri satu sama lain selama kerja. Lebih lanjut penelitian yang dilakukan oleh Radford (2011) telah menghasilkan beberapa cara yang beragam untuk mengkonseptualisasi interaksi dalam kelompok. Radford, (2011) membahas tentang pengembangan metodologi dan alat teoritis untuk menyelidiki intraksi, peran guru, interaksi dan dialog dalam kelas, dan hubungan antara berpikir dan berbicara. Sementara Radford, (2011) mengkaji tentang menata ruangan untuk mendukung proses pembelajaran berlangsung sehingga percakapan siswa dengan siswa langsung dibimbing oleh guru, membentuk kelompok diskusi kecil yang terarah, dan pemecahan masalah secara individu yang didukung oleh komputer dalam pembelajaran kolaboratif. Caca-cara memposisikan siswa dalam kelompok sangat membantu mereka untuk memaksimalkan anggota kelompok ikut aktif mengkontruksi pengetahuan. Keterlibatan anggota dalam diskusi dapat memaksimalkan kontribusi individu serta mudah mencapai tujuan bersama (Nilsson \& Ryve, 2010).

Penelitian tentang kegiatan diskusi kelompok yang mengarahkan siswa untuk memperdebatkan idenya, memberikan kesempatan untuk menyampaikan idenya, atau menyatukan persepsinya dilakukan oleh (Weber, dkk., 2008; Sfard \& Kieran, 2001a). Weber, dkk (2008) menyampaikan bahwa jika siswa sering menantang atau memperdebatkan argumen yang disampaikan oleh rekan-rekannya pada saat menyajikan materi, maka tantangan-tantangan tersebut dapat mengundang siswa secara langsung untuk memahamai tentang prinsipprinsip matematika atau secara tidak langsung sebagai motivasi untuk memahami matematika. Sfard \& Keiran (2001) menjelaskan akan terjadi hasil diskusi yang maksimal jika ucapan-ucapan yang berbeda dari lawan bicara dapat membangkitkan tanggapan yang selaras dengan apa yang diharapan oleh pembicara. Terjadinya saling menanggapi materi yang didiskusikan akan terjadi jika permasalahan yang akan dibahas kadang-kadang sebagian anggota kelompok belum memahaminya dengan baik. Pemahaman tentang materi tertentu oleh setiap siswa memang berbeda-beda. Ada yang benar-benar sudah memahami, ada yang masih kurang, ada yang masih salah, dan bahkan ada yang belum sama sekali memahaminya. Hal ini terjadi karena kemampuan dan cara berpikir seseorang tentang permasalahn tersebut berbeda-beda.

Kegiatan berpikir siswa khusunya tentang matematis selalu bervariasi dan berbeda-beda antara satu siswa dengan siswa yang lainnya. Menyelidiki bervariasinya berpikir siswa tentang matematis ini telah dikaji oleh peneliti (Leatham, dkk., 2015; Van Zoest, dkk., 2017). Leatham, dkk., (2015) menyusun konsep kerangka kerja untuk menganalisis semua contoh pemikiran matematis siswa yang terjadi selama instruksi terjadi di kelas. Van Zoest, dkk., (2017) menyelidiki contoh pemikiran matematis siswa selama interaksi yang diidentifikasi memiliki potensi tinggi. Bentuk pemikiran (misalnya, pertanyaan vs pernyataan deklaratif), apakah pemikiran itu didasarkan pada karya sebelumnya atau yang dihasilkan pada saat itu, akurasi pemikiran, dan jenis pemikiran. Hasil-hasil penelitian ini memberikan gambaran bahwa pemikiran siswa tentang matematika sangat bervariasi. Bervariasinya pemikiran siswa ini dapat kita satukan dalam bentuk diskusi kelompok antara satu siswa dengan yang lainya. Kegiatan interaksi seperti ini selain membantu menyatukan pemahaman siswa tentang materi tertentu, dapat juga membantu dalam memecahkan masalah.

Beberapa penelitian tentang pola interaksi siswa dalam menyelesaikan masalah yang dilakukan dalam berkelompok oleh (Barron, 2003; Watson \& Chick, 2001; Lai \& White, 2014). Barron (2003) Menyelidiki interaksi kolaboratif dapat mempengaruhi hasil pemecahan masalah dan menemukan bahwa kualitas interaksi memiliki implikasi hasil belajar. Watson, dkk (2001) mengidentifikasi kerangka kognitif, sosial, dan faktor lainnya yang mempengaruhi hasil pemecahan masalah yang dicapai selama kolaboratif. Lai \& White, (2014) menyampaikan bahwa pemecahan masalah ketika dilakukan dalam kegiatan diskusi kelompok akan didapatkan dampak postif jika dikoordinir dengan baik dan berdampak negatif jika tidak dikoordinir dengan baik. Pemecahan masalah dilakukan dalam kelompok akan membantu mempercepat menemukan proses penyelesaian masalah. Kegiatan kolaborasi sering dipandang oleh peserta didik untuk mendukung ide satu sama lain dengan menawarkan bagian-bagian yang hilang dari informasi yang diperlukan untuk memecahkan masalah (Francisco, 2013). Lebih lanjut Mueller, dkk., (2012) menyampaikan bahwa siswa dapat bekerja sama dan menanggapi 
pernyataan dari rekan-rekan mereka untuk bersama-sama membangun ide, namun dalam kasus lain siswa dapat menyajikan ide sepenuhnya yang terbentuk dari orang lain untuk memperluas, memodifikasi, atau meragukannya. Proses kegiatan dua arah dalam menstransformasi ide, membangun ide, atau memodifikasi ide antara satu siswa dengan siswa yang lainnya dalam mencari solusi dari permasalahan yang diberikan dalam penelitian ini dinamakan interaksi berpikir.

Syarifudin, dkk., (2019) menyatakan bahwa interaksi berpikir adalah komunikasi antara guru dan siswa dalam proses pembelajaran matematika sehingga terjadi kesesuaian proses berpikir antara guru dan siswa. Proses berpikir terjadi ketika seseorang melakukan interaksi dengan orang lain, baik sesesama siswa, guru atau dengan materi pembelajaran. hal ini sejalan dengan pendapatnya Subanji, (2016) menyatakan bahwa proses berpikir terjadi ketika ada interaksi sosial antar siswa sehingga terjadi proses saling bertukar ide dan mentransfer ide. Lebih lanjut Solso, dkk., (2008) menyatakan bahwa berpikir merupakan kegiatan kognitif yang terjadi secara internal dalam pemikiran, namun keputusan diambil lewat prilaku. Jadi, Interaksi berpikir siswa dalam penelitian ini didefinisikan sebagai hubungan timbal balik dalam berpikir antara dua orang atau lebih melalui berbicara dan bertindak dalam aktivitas diskusi dalam menyelesaikan masalah geometri. Tujuan penelitian ini adalah untuk mendeskripsikan tahap-tahap akktivitas kognitif siswa melalui interaksi berpikir dalam penyelsaian masalah geometri. Kajian penelitian ini lebih fokus pada proses berpikir siswa pada saat kegiatan interaksi dalam diskusi penyelesaian masalah melalui komunikasi mereka. Hasil penelitian ini sangat membantu pendidik untuk mengatur posisi dan kapan saat yang tepat untuk ikut terlibat memberikan bantuan berupa penjelasan kepada siswa yang sedang melakukan diskusi dalam menyelesaikan masalah matematika. Kajian penelitian ini sangat berbeda dengan kajian-kajian penelitian yang lainnya. Kerena penelitian selama ini lebih fokus pada kajian kegiatan interaksi siswa dalam berdiskusi. Penelitian ini menggunakan alat analisis interaksi yang disampaikan oleh Sa'nchez, dkk.

Sánchez, dkk., (2013) telah mengembangkan kerangka analisis untuk menganalisi interaksi verbal siswa dan guru dalam berinteraksi. Dalam penelitian menggunakan analisis tersebut yaitu: pertama kategori Prosedural yang dideskripsikan tentang karakterisasi sifat dalam kegiatan kelompok sebaya ketika pelaksanaan tugas rutinitas tanpa perencanaan yang menyeluruh atau berpikir secara koheren dengan pengambilan keputusan positif tetapi tidak kritis. Kedua kategori Eksplorasi yang dipandang sebagai modus yang paling efektif berkaitan untuk membina berpikir kritis dan perkembangan kognitif (Kumpulainen \& Mutanen, 1999; (Mercer, dkk., 1999) hal ini ditandai dengan "aktivitas kritis dan eksplorasi yang meliputi perencanaan, pengujian hipotesis, evaluasi, dan bereksperimen" (Kumpulainen dan Mutanen 1999; 457). Ketiga kategori Disputational (perselisihan) yang ditandai dengan ketidak setujuan anggota kelompok dalam pengambilan keputusan (Mercer, 1995).

\section{Metode}

Penelitian ini merupakan penelitian kualitatif dengan jenis penelitian deskriptif eksplorasi. Penelitian dilakukan pada Sekolah Menengah Pertama Negeri 2 Grati di kelas 8 semester ganjil. Sekolah ini terletak di Kabupaten Pasuruan dan merupakan salah satu sekolah favorit pada kecamatan Grati. Peneliti memilih 5 orang siswa Sekolah Menengah Pertama (SMP) yang berkemampuan tinggi dan sedang. Pengambilan data dilakukan dengan cara merekam kegiatan diskusi siswa yang sedang menyelesaikan masalah matematika yaitu soal geometri. Hasil rekaman video tersebut akan dibuatkan dalam bentuk transkrip percakapan. Data hasil rekaman video yang sudah diubah menjadi transkrip akan dianalisis dan dipaparkan secara kualitatif. Data yang akan diperhatikan dalam kegiatan interaksi berpikir siswa dalam memecahkan masalah geometri yaitu proses kognitif dengan kegiatan secara prosedural, kegiatan eksplorasi, dan kegiatan disputational (Sa'nchez, dkk, 2013).

\section{Hasil dan Pembahasan}

Kegiatan menyelesaikan masalah matematika pada soal geometri oleh sekelompok siswa dilakukan dengan cara berdiskusi. Jumlah Siswa yang melakukan diskusi yaitu 5 orang dengan disimbolkan S1, S2, S3, S4, dan S5. Siswa berkemampuan tinggi adalah S1, S2, dan S4 sedangkan siswa berkemampuan sedang yaitu S3 dan S5. Kelima siswa ini mengawali penyelesaian masalah dengan memahami soal yang telah disediakan secara individuindividu. Kegiatan diskusi diawali oleh S1 dengan menjelaskan maksud dan tujuan soal. Setelah beberapa anggota kelompok bisa memahami dari soal tersebut, lalu terjadilah kegiatan diskusi untuk mencarikan penyelesaiannya. Berdasarkan hasil recaman vidio dan transkripnya dari kegiatan penyelesaian masalah oleh 
kelima subyek dalam penelitian ini, selanjutnya peneliti menganalisnya dengan alat analisis yang dikembangkan oleh Sa 'nchez, dkk, (2013) yaitu kegiatan secara Prosedural, Perselisihan, dan Eksplorasi.

\section{Kegiatan Secara Prosedural}

Kegiatan secara prosedural merupakan kegiatan yang mendeskripsikan tentang karakterisasi dari sifat kegiatan kelompok sebaya yang dipahami sebagai pelaksanaan tugas rutinitas tanpa perencanaan yang menyeluruh. Kegitan seperti ini dilakukan oleh siswa dalam penyelesaian masalah tanpa berpikir secara koheren dan langsung mengambil keputusan secara positif tetapi tidak kritis. Dalam kegiatan penyelesaian masalah secara prosedural oleh sekelompok siswa dapat dilihat seperti kutipan berikut ini.

1. S1 : ini loh... ada 100 segitiga dan 60 pesegi untuk menyusun kubus, balok, prisma, dan limas (memahami soal sambil mengkomunikasikan ke teman-temannya)

2. S2 : inilah gambar re.... (menanggapinya dari S1 dengan mengilustrasikan dari gambar yang sudah disediakan pada soal dari beberapa segitiga dan persegi.

3. S1 : ya iya trus... lagi (menanggapinya dengan mengerucut penyelesaian tentang kubus)

4. S3 : iya betul.

5. S1 : iya, kita habiskan segitiga dan persegi untuk menyusun kubus, balok, prisma, limas.

Tema diskusi dalam kegaiatan interaksi berpikir yang terjadi pada gari 1-5 tersebut tentang menyusun kubus, balok, prisma, dan limas dari beberapa bagian segitiga dan persegi. Siswa S1 (garis 1) memulai dengan menunjukkan gambar 100 bagian segitiga dan 60 bagian persegi dengan sambil menjelaskan kepada rekanrekannya. Hasil komunikasi diantara mereka ini mengambarkan bahwa semua anggota kelompok menyetujui dari apa yang disamapaikan S1. Hal ini berarti pengetahuan yang dimiliki oleh semua siswa (garis 2-5) terkait dengan permasalahan yang dihadapinya sudah dimiliki dalam pikirannya.

\section{Kegiatan yang Menimbulkan Perselisihan}

Kegiatan ini ditandai dengan ketidak setujuan oleh anggota kelompok ketika saat anggota kelompok yang lain mengambil keputusan. Berikut ini kutipan dalam transkrip kegiatan interaksi berpikir siswa untuk menyelesaikan soal goemetri.

1. S5 : Bagaiman gambarnya limas yang disusn dari persegi (menanyakan tentang gambar yang disusun dari persegi)

2. S1 : Seperti ini (menunjukkan gambar dari jawabannya)

3. S2 : begini ya? (melihat jawaban yang ditunjukkan oleh S1)

4. S3 : Mana sih..

5. S4: Oh ... (ikut melihat juga)

6. S5 : Kok seperti itu? Apa tidak seperti ini? (S5 menunjukkan gambar yang telah ditulisnya)

7. S2: Kan seperti ini boleh juga.

8. S1: Sama aja, yang penting akan tergamnar limas yang tersusun dari setiga dan segiempat.

9. S4 : Seperti ini (menjelaskam ke s1 tentang jawaban dari dia).

10.S2 : Seperti ini (menegaskan ke s5).

11.S1 : Seperti ini loh (juga ikut menegaskan),

12.S5 : Oh .... (mengalami kebingungan)

13.S4 : Seperti ini, inikan segiempat dan segitiga, yang kamu tulis itu dua segitiga yang gabungkan menjadi segiempat. (menjelaskan)

14.S1 : Betul... (dan semau ikut melihan dan mendengarkan penjelasan dari s4),

15.S5 : Saya paham... (ikut menegaskan penjelasan dari s4) 
16.S1 : Sebenarnya tidak kita susun dengan segitiga semua atau ada persegi tetap bisa (ikut menegaskan dengan cara yang berbeda)

Dialog tersebut menjelaskan tentang kegiatan siswa menyelesaikan masalah untuk menggambar limas. Kegiatan interaksi berpikir diawali dari S5 (garis 6) yang menanyakan tentang cara mengambar limas yang disusun dari persegi. Pada dialog tersebut, S1 (garis 7) langsung merespon dengan menunjukkan jawabanya ke S5 dan begitupun oleh siswa-siswa yang lainnya. Namun S5 (garis 11) masih bingung dan membutuhkan penjelasan dari anggota kelompok yang lainnya. S2 (garis 15) melajutkan penjelasanya ke S5 dan dipertegas lagi oleh S1 (garis 16 dan 21) dan S4 (garis 18).

\section{Kegiatan Eksplorasi}

Kegiatan ini ditandai dengan adanya aktivitas kritis dan eksplorasi oleh anggota kelompok yang meliputi perencanaan, pengujian hipotesis, evaluasi, dan bereksperimen. Berikut ini adalah kegiatan interaksi berpikir siswa pada kategori ekplorasi dalam penyelesaian masalah geometri.

1. S2 : Kalau 20 persegi untuk menyusun balok bagaimana?

2. S1 : Empat (alas dan atas), empat (depan dan belakang), dan dua (kiri dan kanan). (menghitung sisi dari balok, apabila persegi digunakan untuk menyusun sisi balok)

3. S4 : Iya betul (sambil menghitung juga sisi-sisi dari balok)

4. S5: Iya wes (ikut menggambar)

5. S3 : Satu, dua, ... , sepuluh (menghitung persegi yang bisa digunakan untuk menyusun gambar balok)

6. S1 : Ikiloh... (menghitung ulang berapa persegi yang dibutuhkan untuk menyusun balok)

7. S2 : Oh begitu (sambil melanjutkan lagi gambarnya)

8. S5 : Seperti ini ya gambarnya (sambil menunjukkan hasil gambarnya)

9. S1 : Iya seperti itu, tapi dikasih putus-putus (mengambar garis putus-putus)

10.S2 : Oke ... (sambil mengambar dan kadang-kadang sambil lihat jawaban dari S1, namuan cara memberikan nama balok berbeda dengan S1)

11.S3 : Ini ya, (sambil menulis angka 1, 2, .., 10 pada balok yang menunjukkan banyaknya persegi)

12.S4 : Oke ... (mengambar balok dengan menilis 1, 2, ..., 10 pada balok yang menunjukkan banyaknya persegi)

13.S5 : Seperti ini ya, (dia menulis huruf ABIJ, IJDM, ... yang ada pada gambar Balok)

Kegiatan pada dioalog tersebut menjelaskan tentang interaksi berpikir siswa dalam menggambar balok. Kegaitan diawali dari pernyataan oleh S2 (garis 22) tentang ada 20 persegi untuk menyusun balok. Kegiatan tersebut langsung direspon oleh S1, S4, S5, dan S3 (garis 23-26) untuk menghitung berapa persegi yang dibutuhkan dalam menyusun gambar balok. S1 menegaskan lagi tentang jumlah persegi yang dibutuhkan dalam mengambar balok. Pada akhir kegiatan dialog dalam interaksi berpikir ini siswa masing-masing mengambar balok sesuai dengan yang dipahaminnya. Mereka mengambar dengan memberi nama balok tersebut beragam. Misalnya S4 (garis 33) menuliskan angka 1, 2, ... pada masing-masing sisi yang berbentuk persegi pada gambar balok.

\section{Pembahasan}

Hasil menarik yang akan dibahas dalam penelitian ini adalah kegiatan interaksi berpikir subyek dalam memecahkan masalah diawali dengan saling menguatkan pemahaman terhadapat permasalahan dari soal yang telah disediakan. Subyek saling memberikan persepsi dari hasil pemahaman mereka terhadap soal yang diberikan. Dimana subyek yang satu dengan yang lainnya saling memberikan pernyataan tentang jawaban yang akan ditulis bersama-sama. Hal ini sejalan dengan pendapatnya Gresalfi, dkk., (2009) menyatakan terjadi proses negosiasi diperlukan untuk saling memperkuat jawaban dari cara berpikir masing-masing. Kegiatan saling memberikan jawaban ini tidak cukup dengan lisan saja. Ternyata masih ada subyek yang belum yakin atas jawaban dari kesepakatan secara lisan dan masih melihat jawaban dari temannya. Kegiatan ini akan diawali oleh S1 menjelaskan maksud dan tujuan dari masalah yang ada pada soal disediakan. 
Semua subyek memahami soal yang diberikan, disini S1 berkemampuan tinggi mengawalinya dengan memberikan tutorial kepada semua teman-temanya tentang permasalahan yang akan diselesaikan. Hal ini dapat dilihat pada kegiatan dialog yang ada pada kegiatan secara prosedural, kegiatan menimbulkan perselisihan, dan kegiatan eksplorasi (garis 1, 7, dan 23). Subyek-subyek yang lainnya masih ada yang bingung dan bertanya-tanya ke temannya sehingga terjadilah kegiatan kolaboratif untuk menyelesaikan masalah tersebut (garis 9, 11, 17, dan 29). Hal ini sejalan dengan pendapatnya Bishop, (2012) menyatakan bahwa cara orang berbicara dan berinteraksi sangat kuat dipengaruhi oleh kemampuan mereka. Kemampuan individu dalam mengidentifikasi permasalahan yang diberikan akan dipengaruhi oleh pengalaman dan pengetahuan dari individu itu sendiri (Stacey, 2014). Pengalaman dan pengetahuan yang tersimpan di memori akan mempengaruhi pemahaman setiap individu terhadap stimulus yang datang. Pengalaman akan memberikan bentuk dan struktur bagi objek yang ditangkap panca indera, sedangkan pengetahuan akan memberikan arti terhadap objek yang ditangkap individu, dan akhirnya komponen individu akan berperan dalam menentukan tersedianya jawaban yang berupa sikap dan tingkah laku individu terhadap objek yang ada (Bado \& Franklin, 2014) dan juga menjelaskan bahwa pemahaman seseorang bergantung pada seberapa luas orang tersebut telah mempelajari stimulus tersebut pada pembelajaran sebelumnya.

Subyek yang masih belum memiliki pengetahuan dan pengalaman yang tersimpan dalam memori akan kesulitan menjelaskan dari permasalahan yang ada sehingga membutuhkan penjelasan dari teman-temannya (garis 6, 9, dan 11). Disini akan terjadi interaksi berpikir subyek-subyek yang sudah memiliki pengetahuan dan pengalaman sebelumnya (garis 3,4, dan 5). Subyek yang sudah memiliki akan menjelaskan kepada temantemannya. Begitupun sebaliknya, bagi subyek yang belum memilikinya akan menerima pengetahuan dan pengalaman tersebut. Dari hasil interaksi antar siswa ini, terlihat bahwa interaksi yang terjadi sesuai dengan pandangan Vygotsky (1972) mengenai scaffolding, yaitu satu anak bisa lebih membimbing anak yang lain dalam melewati ZPD (Zone of Proximal Development). Siswa yang belum memiliki pengetahuan tentang permasalahan yang akan diselesaikan akan melakukan sebagian kesalahan identifikasi terhadap asumsi yang diberikan pada saat menyampaikan pendapatnya, sehingga mengakibatkan persepsi yang keliru dan menimbulkan kesalahan pada jawabannya. Proses identifikasi yang salah tersebut dikarenakan adanya pemahaman konsep yang salah dan terbatas yang tersimpan di memori. Sebagai akibatnya adalah subyek dengan pemahaman dan pengalaman kurang mempunyai percepsi yang salah terhadap stimulus dan kesulitan dalam memilih strategi maupun menentukan langkah awal dari jawabannya. Hal tersebut sesuai dengan hasil penelitian (Jenness, dkk., 2007; Barnard \& Tall, 1997; Chen, 2008) yang menyatakan bahwa penyebab awal kegagalan siswa dalam menjawab soal disebabkan oleh kurangnya pengetahuan konseptual dan pengetahuan strategik.

Ketika semua subyek sudah saling tahu dan paham atas jawaban dari hasil tukar menukar ide atau kegiatan interaksi berpikir mereka melalui komunikasi, selanjutnya masing-masing subyek secara individual akan menulis jawaban pada lembar jawaban yang sudah disediakan (garis 32-34). Jawaban sudah ada akan direpresentasikan dalam bentuk yang nyata. Disni ditemukan juga subyek yang belum percaya diri menulis jawabannya dari hasil pemikirannya sendiri. Artinya pada working memory subyek jawaban yang sudah disepakati bersama-sama belum lengkap. Kemungkinan ini terjadi karena belum seutuhnya si penerima informasi masih belum paham atau belum lengkap informasih yang diterimanya. Beberapa subyek masih melihat ulang dari jawaban temannya yang sudah tertuang dalam bentuk nyata. Hal ini sesuai dengan pendapatnya Kieran (2002) menyatakan bahwa penyampaian informasi yang belum lengkap akan ditanggap balik oleh si penerima informasi baik secar lisan atau melihat tulisan si pemberi informasi. Setelah melihat ulang jawaban dari teman-temannya, barulah beberapa subyek tadi menuliskan jawabannya sendiri. Sehingga jawaban dari semua anggota kelompok dapat berkembang dari yang sudah dimiliki dengan pengetahuan yang didapat dari penjelasan siswa lain.

Menulis jawaban dari hasil kesepakatan semua anggota kelompok akan mengarah pada cara merepresentasikannya sama. Pada kenyataanya ternyata masing-masing subyek memiliki cara merepresentasikannya jawabanya sendiri-sendiri (garis 33 dan 34). Kelima subyek menuliskannya dengan caranya sendiri. Pengetahuan dan pemahaman mereka akan jawaban ini sudah direcam pada long term memory mereka masing-masing. Cara siswa menjawab soal yang diberikan tergantung pola kegiatan interaksi mereka. Pola kegiatan interaksi memiliki hubungan dengan hasil pemecahan masalah. Hal ini sejalan dengan hasil penelitian yang diteliti oleh (Barron, 2000, 2003; Lai \& White, 2014; Watson \& Chick, 2001). 


\section{Simpulan}

Kegiatan interaksi berpikir siswa dalam memecahkan soal geometri diawali dengan satu anggota kelompok yang berkemapuan tinggi memberikan pernyataan dan penjelasan dari permasalahan yang disediakan. Siswa yang lainya mendengarkan dan kadang-kadang memberikan unpan balik berupa pertanyaan atau penjelasan lebih lanjut. Kegiatan selanjutnya adalah kelima siswa bersama-sama mendiskusikan dan saling membantu untuk mencari solusi dari permasalah yang diberikan dengan menyampaikan penjelasan atau pertanyaan sesuai dengan tingkat pengetahuan yang dimilikinya. Selain bekerja secara tim, kegiatan ini didominasi oleh siswa yang berkemampuan tinggi untuk memimpin diskusi atau memuncukan ide dalam menyelesaikan masalah maupun mengarahkan jawaban untuk ditulis secara bersama-sama. Sedangkan siswa berkemapuan sedang hanya mengikuti dan kadang-kadang menanyakan ulang jawaban yang sudah diputuskan. Terjadi juga saling memberi dan mempertahankan argumentasi dari jawaban yang sudah disampaiakan antara siswa berkempuan tinggi dengan tinggi atau tinggi dengan sedang. Kegiatan secara individual dilakukan ketika sudah menemukan jawaban dari hasil keputusan bersama-sama. Setelah mereka menulis jawaban masing-masing, ternyata bentuk jawaban yang dituliskan berbeda-beda dan ada juga yang masih melihat jawaban dari temannya.

\section{Daftar Pustaka}

Anderson, L. W., \& Krathwohl, D. R. (2010). Kerangka landasan untuk pembelajaran, pengajaran, dan asesmen. Yogyakarta: Pustaka Pelajar, 300(300), 0.

Bado, N., \& Franklin, T. (2014). Cooperative Game-based Learning in the English as a Foreign Language Classroom. Issues and Trends in Educational Technology, 2(2), 1-17. https://doi.org/10.2458/azu_itet_v2i2_bado

Barnard, T., \& Tall, D. (1997). Cognitive units, connections and mathematical proof. PME Conference, 2, 2-41.

Barron, B. (2000). Achieving coordination in collaborative problem-solving groups. Journal of the Learning Sciences, 9(4), 403-436. https://doi.org/10.1207/S15327809JLS0904_2

Barron, B. (2003). When smart groups fail. Journal of the Learning Sciences, 12(3), 307-359. https://doi.org/10.1207/S15327809JLS1203_1

Bishop, J. P. (2012). "She's always been the smart one. I've always been the dumb one": Identities in the mathematics classroom. Journal for Research in Mathematics Education, 43(1), 34-74. https://doi.org/10.5951/jresematheduc.43.1.0034

Chen, Y. (2008). from Formal Proofs to Informal Proofs-Teaching Mathematical Proofs with the Help Of Formal Proofs. International Journal of Case Method Research EO Application, XX(4), 398-402.

Francisco, J. M. (2013). Learning in collaborative settings: Students building on each other's ideas to promote their mathematical understanding. Educational Studies in Mathematics, 82(3), 417-438. https://doi.org/10.1007/s10649-012-9437-3

Gresalfi, M., Martin, T., Hand, V., \& Greeno, J. (2009). Constructing competence: An analysis of student participation in the activity systems of mathematics classrooms. Educational Studies in Mathematics, 70(1), 49-70. https://doi.org/10.1007/s10649-008-9141-5

Jenness, V., Smith, D. A., \& Stepan-Norris, J. (2007). Advances in Sociological Thinking about Interaction: Ritual Chains, Institutional Talk, Cognition, Humor, and Laughter. Contemporary Sociology: A Journal of Reviews, 36(3), vii-viii. https://doi.org/10.1177/009430610703600302

Johnson, D. W., Johnson, R. T., \& Smith, K. (2007). The state of cooperative learning in postsecondary and professional settings. Educational Psychology Review, 19(1), 15-29. https://doi.org/10.1007/s10648-0069038-8

Kidron, I., Lenfant, A., Bikner-Ahsbahs, A., Artigue, M., \& Dreyfus, T. (2008). Toward networking three theoretical approaches: The case of social interactions. ZDM - International Journal on Mathematics Education, 40(2), 247-264. https://doi.org/10.1007/s11858-008-0079-y

Kumpulainen, K., \& Mutanen, M. (1999). The situated dynamics of peer group interaction: An introduction to 
an analytic framework. Learning and Instruction, 9(5), 449-473. https://doi.org/10.1016/S0959. 4752(98)00038-3

Lai, K., \& White, T. (2014). How groups cooperate in a networked geometry learning environment. Instructional Science, 42(4), 615-637. https://doi.org/10.1007/s11251-013-9303-4

Leatham, K. R., Peterson, B. E., Stockero, S. L., \& Van Zoest, L. R. (2015). Conceptualizing mathematically significant pedagogical opportunities to build on student thinking. Journal for Research in Mathematics Education, 46(1), 88-124. https://doi.org/10.5951/jresematheduc.46.1.0088

Mercer, N. (1995). The guided construction of knowledge: Talk amongst teachers and learners. Multilingual matters.

Mercer, N., Wegerif, R., \& Dawes, L. (1999). Children's talk and the development of reasoning in the classroom. British Educational Research Journal, 25(1), 95-111.

Mueller, M., Yankelewitz, D., \& Maher, C. (2012). A framework for analyzing the collaborative construction of arguments and its interplay with agency. Educational Studies in Mathematics, 80(3), 369-387. https://doi.org/10.1007/s10649-011-9354-x

Nilsson, P., \& Ryve, A. (2010). Focal event, contextualization, and effective communication in the mathematics classroom. Educational Studies in Mathematics, 74(3), 241-258. https://doi.org/10.1007/s10649-010-92367

Radford, L. (2011). Book Review: Classroom Interaction: Why is it Good, Really? Baruch Schwarz, Tommy Dreyfus and Rina Hershkowitz (Eds.) (2009) Transformation of knowledge through classroom interaction. Educational Studies in Mathematics, 76(1), 101-115. https://doi.org/10.1007/s10649-010-9271-4

Sánchez, V., García, M., \& Escudero, I. (2013). An analytical framework for analyzing student teachers' verbal interaction in learning situations. Instructional Science, 41(2), 247-269. https://doi.org/10.1007/s11251012-9226-5

Santagata, R., Zannoni, C., \& Stigler, J. W. (2007). The role of lesson analysis in pre-service teacher education: An empirical investigation of teacher learning from a virtual video-based field experience. Journal of Mathematics Teacher Education, 10(2), 123-140. https://doi.org/10.1007/s10857-007-9029-9

Sfard, A., \& Kieran, C. (2001a). Cognition as communication: Rethinking learning-by-talking through multifaceted analysis of students' mathematical interactions. Mind, Culture, and Activity, 8(1), 42-76.

Sfard, A., \& Kieran, C. (2001b). Cognition as communication: Rethinking learning-by-talking through multifaceted analysis of students' mathematical interactions. Mind, Culture, and Activity, 8(1), 42-76. https://doi.org/10.1207/S15327884MCA0801_04

Solso, R. L., Maclin, O. H., \& Maclin, M. K. (2008). Psikologi Kognitif Edisi Kedelapan (terjemahan). Erlangga, Jakarta.

Stacey, K. (2014). What Is Mathematical Thinking and Why Is It Important? Research in Mathematics Education, 15(2),

http://login.ezproxy.lib.umn.edu/login?url=http://search.ebscohost.com/login.aspx?direct=true\&Auth Type $=$ ip, uid\& $\mathrm{db}=$ eric\& $A \mathrm{~N}=\mathrm{EJ} 1018630 \&$ site $=$ ehost-live

Stockero, S. L., \& Van Zoest, L. R. (2013). Characterizing pivotal teaching moments in beginning mathematics teachers' practice. Journal of Mathematics Teacher Education, 16(2), 125-147. https://doi.org/10.1007/s10857-012-9222-3

Strom, D., Kemeny, V., Lehrer, R., \& Forman, E. (2001). Visualizing the emergent structure of children's mathematical argument. Cognitive Science, 25(5), 733-773. https://doi.org/10.1016/S03640213(01)00052-0

Subanji, S. (2016). Berpikir pseudo penalaran kovariasi dalam mengkonstruksi grafik fungsi kejadian dinamik: Sebuah analisis berdasarkan kerangka kerja VL2P dan implikasinya pada pembelajaran matematika. Jurnal Ilmu Pendidikan, 13(1). 
Syarifudin, Purwanto, Irawan, E. B., Sulandra, I. M., \& Fikriyah, U. (2019). Student verbal interaction in geometry problem-solving through cognitive activities. International Journal of Instruction, 12(3), 167-182. https://doi.org/10.29333/iji.2019.12311a

Van Zoest, L. R., Stockero, S. L., Leatham, K. R., Peterson, B. E., Atanga, N. A., \& Ochieng, M. A. (2017). Attributes of Instances of Student Mathematical Thinking that Are Worth Building on in Whole-Class Discussion. Mathematical Thinking and Learning, 19(1), 33-54. https://doi.org/10.1080/10986065.2017.1259786

Watson, J. M., \& Chick, H. L. (2001). Factors Influencing the Outcomes of Collaborative Mathematical Problem Solving: An Introduction. Mathematical Thinking and Learning, 3(2-3), 125-173. https://doi.org/10.1080/10986065.2001.9679971

Weber, K., Maher, C., Powell, A., \& Lee, H. S. (2008). Learning opportunities from group discussions: Warrants become the objects of debate. Educational Studies in Mathematics, 68(3), 247-261. https://doi.org/10.1007/s10649-008-9114-8 